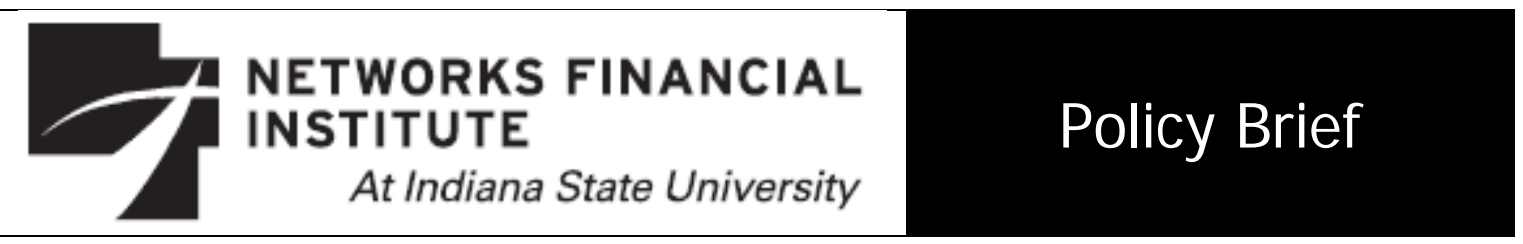

2010-PB-01

March 2010

\title{
The Financial Turmoil of 2007-09: Sinners and Their Sins George G. Kaufman
}

Abstract: The causes of the financial crisis of 2007-09 are many and varied. Indeed, the crisis may be viewed as the product of a perfect storm. This paper identifies the major culprits or sinners of the U.S. crisis and enumerates their more important sins. The culprits include central bankers, commercial bankers, credit rating agencies, financial engineers, the government, investors, mortgage borrowers, mortgage brokers, and prudential bank regulators. Among the numerous sins committed by these sinners, the role of the government in encouraging and subsidizing risky home mortgages and the poor performance of the prudential regulators in adequately enforcing the in-place rules are of particular concern. The regulators were poor agents for their healthy bank and taxpayer principals. It follows that prevention of future crisis requires the development of better incentives to motivate the regulators to be more faithful to the letter and spirit of the regulations.

About the Author: George G. Kaufman is the J ohn F. Smith Professor of Finance and Economics and Director of the Center for Financial and Policy Studies in the School of Business Administration, Loyola University, Chicago. Before teaching at Loyola, he was a research fellow, economist and research officer at the Federal Reserve Bank of Chicago and has been a consultant to the Bank since 1981. Kaufman received his B.A. from Oberlin College, M.A. from the University of Michigan, and Ph.D. in economics from the University of Iowa. Professor Kaufman's teaching and research interests are in financial economics, institutions, markets and regulation and in the Federal Reserve and monetary policy. He has lectured widely in the U.S. and abroad and published extensively in professional journals, as well as having been an editor or a member of the editorial board of several major journals. He is also the author or editor of numerous books. In May 2003, the Economist identified Kaufman as one of "America's leading financial economists." Professor Kaufman has served as a consultant to numerous government agencies and private firms. He has frequently testified before Congress and other legislative and policy groups.

Keywords: Financial Crisis, Banking, Financial Regulation J EL Classifications: G01, G21, G28, G18

The views expressed are those of the individual author and do not necessarily reflect official positions of Networks Financial Institute. Please address questions regarding content to George Kaufman at gkaufma@luc.edu. Any errors or omissions are the responsibility of the author. NFI working papers and other publications are available on NFI's website (www.networksfinancialinstitute.org). Click "Thought Leadership" and then "Publications/Papers." Earlier versions of this paper under various titles were presented at a meeting of the Swiss Coatings Industry Federation, Zurich, Switzerland, November 13, 2008; the "Symposium on Financial Crisis and Bank Resolution," University of Warwick, Coventry U.K., April 16-17, 2009; the Finlawmetrics Conference at Bacconi University, Milan, Italy, J une 18-19, 2009; the summer meetings of the International Banking, Economics, and Finance Association, Vancouver, Canada, J une 30-J uly 2, 2009; the University of New Mexico, November 13, 2009; a conference organized by the Spanish Savings Banks Foundation, Madrid, Spain, January 21, 2010; and at Oberlin College, March 3 2010. Shorter earlier versions are published in J. Raymond LaBrosse, Dalvinder Singh and Rodrigo Olivares-Caminal, eds., Financial Crisis Management and Bank Resolution, Informa Publishers (2009), as a Heartland Institute Policy Brief (2010), and in a Spanish translation in Papeles De Economia Espanola 122 (2010). I am indebted to Richard Porter, Catherine Lemieux, Erik Gerding, Ethan CohenCole and participants at the above conferences for helpful comments and suggestions. 


\section{The Financial Turmoil of 2007-09: Sinners and Their Sins George G. Kaufman}

The financial crisis that started in the summer of 2007 in the subprime mortgage market in the U.S. and spread quickly both to other financial sectors and throughout much of the globe was the most severe such crisis since the Great Depression of the early 1930s, with similar but less severe adverse consequences for the domestic and global macroeconomies. The depth and breadth of the meltdowns, in terms of the costly failure of large banks and bank-like institutions and the resulting reductions in aggregate wealth, and adverse feedback to the real sector that may have precipitated the economic downturn in 2008 and deepened the depth of the recession, have intensified the search for public policy strategies that will mitigate the probability and minimize the cost of experiencing similar crises in the future.

The design and enactment of effective corrective public policies requires the correct identification and understanding of the root causes of the crisis and the means by which it was transmitted. That is, getting it right requires knowing what went wrong! Remedial policies enacted should neither throw out the baby (financial system) with the bathwater nor destroy the financial system in order to save it. Based on the available analyses of the causes and growth of the crisis, this paper identifies the main culprits or sinners in the United States and the more major sins they committed. Although this paper limits itself to the U.S., because the crisis was global, many of the sinners in the U.S. have similar guilty counterparties abroad. Thus, much of the analysis herein applies also to other countries.

The U.S. and world crisis were both triggered primarily by the end of the housing price bubble in the U.S. starting in 2006. If there had been no real estate bubble, there 
probably would not have been as severe a problem. The first indication of trouble was the failure in the summer of 2007 of two medium-sized German banks and a few relatively small U.S. and French hedge funds, due to investments in securitized U.S. subprime mortgages. But only shortly afterwards, the first visible bank run in the U.K. in over 100 years occurred at the mortgage specialist Northern Rock Bank, which had been weakened by bad mortgage loans and excessive reliance on wholesale short-term funding. The run, mostly by retail depositors, was amplified by a poorly designed British deposit insurance system that effectively encouraged insured depositors at troubled institutions to withdraw their deposits. ${ }^{1}$ The run saw long lines in front of the bank's offices, which were widely reported by the British news media and ignited widespread public concern about the apparent fragility of the U.K. financial system. The crisis was off and running! ${ }^{2}$

\section{U.S. Sinners}

Downturns or crises expose sins that may have long existed but were covered up or hidden during the good or boom times when asset prices increase rapidly. Few if any investors in these "too-good-to-be-true” projects sell or request withdrawals. It is the attempt to sell and withdraw funds when the boom ends that generally exposes the sinners. ${ }^{3}$ As the successful investor Warren Buffet has observed, it is "only when the tide goes out that you can learn who’s been swimming naked.” Sins continue to accumulate in the booms until the last one is one too many and breaks the camel's back. As noted above, in 2007, the final straw was the end of the housing price bubble in the

\footnotetext{
${ }^{1}$ Eisenbeis and Kaufman (2009).

${ }^{2}$ For good reviews of the crisis, see BIS (2009), Hoenig (2008), and Acharya and Richardson (2009).

${ }^{3}$ For examples, see the Charles Keating scandal during the S\&L crisis of the 1980s, the Enron collapse in the recession of 2001, and the Bernard Madoff debacle during the 2007-08 financial crisis.
} 
U.S. The list of sinners who contributed to the crisis is long and the culprits are housed in a broad array of sectors, both private and public. There were both market and regulatory failures. In the words of the old U.S. comic strip hero, Pogo, "We have met the enemy and he is us."

The depth of the 2007-09 crisis was the result of a perfect storm. If any of the sinners had not contributed, the severity of the turmoil would have been considerably smaller. The sinners, in alphabetical order, include ${ }^{4}$ :

- Central bankers (monetary policy)

- Commercial bankers (initial and ultimate lenders)

- Credit rating agencies

- Financial engineers

- Government (Congress and the administration)

- Investors (ultimate lenders)

- Mortgage borrowers

- Mortgage brokers (salesmen)

- Prudential bank regulators

Some of their more important sins are catalogued and described below.

\section{Central Bankers}

It could be argued that the Federal Reserve maintained short-term interest rates too low for too long in the early 2000s after the end of the 2001 recession so that shortterm real rates were frequently negative. If this caused long-term rates also to be lower

\footnotetext{
${ }^{4}$ I have omitted academics, who should also share in the blame for, on the whole, seeing neither the crisis coming nor its depth when it did come. But it is difficult to bite the hand that feeds you! Another potential guilty party may be the accounting firms, who performed poorly as gate keepers, but their role awaits further investigation.
} 
than appropriate, it is likely to have both helped fuel the sharp rise in housing prices nationwide and encouraged excessive corporate and household leverage, particularly by investment banks and residential and commercial mortgage borrowers. ${ }^{5}$ Moreover, the Fed appears not to have been sufficiently sensitive to the potential severity of any adverse impact of a potential bursting of the housing bubble on the banking system and the macroeconomy and did not cushion them sufficiently. It also underestimated the full magnitude of the impact on current and future aggregate consumption and on the riskiness of mortgages of equity extractions from residential mortgages when household borrowers refinanced their homes, ever increasing in price, at lower interest rates. Households effectively used their homes as ATMs, which would be closed if home prices stopped climbing.

Lastly, the Fed often confused an underlying solvency problem at the banks for a liquidity problem and delayed in applying the appropriate remedial policies. It flooded the market with liquidity rather than repairing the capital positions of the banks. Ironically, although financial stability was a major reason for the establishment of the Federal Reserve in 1913, the objective appears to have been downgraded in more recent years to monetary stability.

\section{Commercial Banks (Bankers)}

The banks operated with far too little correctly measured capital (excessive leverage) for their scale of operations and the risks they assumed. They increasingly based their origination of residential mortgage loans more on expected continued

\footnotetext{
${ }^{5}$ E.g. Taylor (2009). Whether interest rates were too low for too long is open to debate and, even if low in retrospect, they were not the only cause of the housing price bubble (Bernanke 2010). Other factors include a breakdown in mortgage underwriting standards that increased both the supply of mortgage funds and the demand for home ownership (discussed later) and the enactment of favorable tax laws on gains from the sale of primary residences in 1997.
} 
increases in housing prices rather than on the ability of the home buyer to meet monthly payments out of his/her current income. Home mortgages took on more characteristics of asset-backed loans than income-backed loans.

The banks engaged in poor and insufficient credit analysis of residential and commercial mortgage borrowers and outsourced much of the credit analysis to credit rating firms for the complex securitized mortgage instruments that they originated or purchased on the capital markets. The banks introduced compensation schemes for a wide range of employees that relied heavily on loan production and sales rather than on loan collection and on performance over too short a time period for most defaults and other losses to occur. Such schemes encouraged excessive risk taking at many levels in the organization. Senior management and the banks' boards of directors frequently had poor controls for evaluating the risk incentives that these compensation schemes encouraged both at their own and lower levels in the organization.

The banks also tended to hold in their own portfolios primarily the senior, AAArated tranches of the complex mortgage-based securities, such as collateralized debt obligations (CDOs) - securities backed by other securities - that they packaged and sold rather than the junior, lower-rated riskier tranches. The latter would have required more careful monitoring and may have provided earlier signals of trouble. The banks may also have over-relied on the promised benefits of diversification across geographical and income lines, which tends to disappear in a crisis as all correlations approach one.

The banks created many of the CDOs outstanding, but did so generally through off-balance sheet entities, such as structured investment vehicles (SIVs), to reduce the banks' reported risk exposures and any associated regulatory requirement for additional 
capital. The banks sold streams of pooled cash flows from their whole long-term mortgages or mortgage backed securities to the SIVs. The SIVs, in turn, financed them by borrowing short-term, say, in the form of asset-backed commercial paper (ABCP), and transformed them into multi-tranched longer-term securities. The borrowing would be repaid when the CDOs were sold. But, at any sign of concern about the value of the CDOs before sale, the lenders could "run" on the SIVs in the form of not rolling over maturing funding and force fire-sale losses on the hasty sales of the CDOs. Moreover, as the name of the originating bank was associated with the CDO, there were often implicit agreements that, to minimize their reputational risk, the banks themselves would repurchase their CDOs that encountered credit problems, both while awaiting sale in the SIV and occasionally even after sale to investors. Such repurchases puts them back on the issuing banks’ balance sheets.

In both their collection of data on the volume of CDOs and CDO-like securities and their monitoring of performance to measure the risk exposure of banks, bank regulators failed to recognize the contingent liability of the banks and did not fully include the obligations of the SIVs. Thus, they greatly underestimated both the size of the CDO market and the risk exposure of the banks. CDOs and CDO-like tranched derivative securities were not only highly complex and opaque, but were new to the market and as such carried innovation risk, as does almost any new product in addition to the other more usual and understood risks. This increased the total risk to the banks and other investors and the likelihood of these securities “crashing” more often than older, more familiar securities until their characteristics were better understood. 


\section{Credit Rating Agencies}

The credit rating agencies, who are widely viewed as gatekeepers, conducted incomplete and sloppy credit analyses of the new and complex mortgage securitized products, such as CDOs, particularly with respect to their estimated losses given default. In their stress testing, the agencies basically assumed that there would be no major nationwide bursting of the real estate price bubble, as no such serious price declines had occurred in their recent memory. Thus, they failed to include unfavorable extreme or tail values in their test simulations. As long as house prices kept rising, homes that were foreclosed and sold because of mortgage defaults were assumed to be sold at small, if any, losses and credit ratings on the new securities were assigned accordingly.

Although the agencies appear to have been reasonably correct on their estimates

of the probability of default for individual mortgages, they badly underestimated portfolio correlations at times of crisis, particularly for subprime and similar risky mortgages, and thus the defaults for CDO portfolios. The benefits of diversification are greatly diminished during crises when most individual securities became impacted by the same general forces. When the bubble burst and house prices declined sharply, losses from defaults and subsequent foreclosure sales were substantially larger than anticipated and assumed in the ratings assigned. As defaults increased, the higher rated tranches of the multi-tranched CDO securities, which received the first cash flows from the underlying mortgages, were downgraded, often numerous ratings at a time, as the junior tranches, which receive the later cash flows and cushion the higher rated tranches, suddenly received smaller or no payments and became worth less, or even worthless. 
The agencies also failed to emphasize sufficiently to rating user investors, or denied altogether, that the letter grade assigned was basically a relative grade within a given class of securities and not across security classes. ${ }^{6}$ A complex AAA CDO is not the same credit quality as a plain vanilla AAA corporate bond, which in turn is not the same as a plain vanilla AAA municipal bond. Indeed, the spreads on these three bonds differ greatly, being significantly higher for the CDO. Because the rating fee is paid by the issuer (sell side), the issuer may be able to influence the rating obtained by threatening to use another agency or none at all if the rating the agency would assign was too low.

As is discussed later, the agencies may also be pressured by some investors to upgrade ratings so that investors who are restricted to higher-rated securities by legislation or regulation, e.g., money market funds, would have more eligible securities in which to invest. The poor performance of the agencies may also be blamed in part on the lack of penalties for poor performance, other than loss of reputation, and a lack of competition, as the U.S. Securities and Exchange Commission made entry into the industry difficult. The agencies argue that their ratings are only opinions currently protected by the constitutional freedom of speech provisions of the First Amendment.

\section{Financial Engineers}

Banks hired financial engineers, who were often more knowledgeable in quantitative skills than in finance, both to quantify the risk exposures of the institution and to develop new securities. The models and securities developed were primarily made possible by the exponential growth in computer and telecommunication technology that increasingly permitted greater storage, ever more rapid processing, and more rapid transmission of very large bodies of data. This encouraged the development of more

\footnotetext{
${ }^{6}$ Mason and Rosner (2007).
} 
complex models and securities than market participants had previous experience with and introduced significant innovation risk. The complexity of the risk models developed were often beyond the ability of even senior financial executives to understand thoroughly and fully appreciate their own institution’s risk exposure (black box risk). Likewise, many of the securities innovated, particularly derivative securities, were not only highly opaque, but also highly complex and highly leveraged and beyond the ability of many bankers and investors to understand thoroughly. For example, it has been estimated that a single mortgage CDO could pool as many as 750,000 individual whole mortgages with accompanying documentation running some 30,000 pages. $^{7}$

But these securities could be made even more complex. Tranches of different types of individual CDOs could be combined into a new $\mathrm{CDO}^{2}$. Scott and Taylor describe one such example - a \$1billion $\mathrm{CDO}^{2}$ created by a large bank in 2005 - as follows:

It had 173 investments in tranches issued by other pools: 130 CDOs, and also 43 CLOs each composed of hundreds of corporate loans. It issued $\$ 975$ million of four AAA tranches and three subordinate tranches of \$55 million ... Two of the 173 investments held by this $\mathrm{CDO}^{2}$ were in tranches from another billion-dollar CDO - created by another bank earlier in 2005 - which was composed mainly of the $155 \mathrm{MBS}$ tranches and 40 CDOs. Two of these $155 \mathrm{MBS}$ tranches were from a $\$ 1$ billion RMBS created in 2004 by a large investment bank, composed of almost 7,000 mortgage loans (90\% subprime). That RMBS issued $\$ 865$ billion of AAA notes, about half of which were purchased by Fannie Mae and Freddie Mac and the rest by a variety of banks, insurance companies, pension funds and money managers. $^{8}$

By creating new tiers of securities layered on previous tiers, these securities increased the total amount of debt secured by the same underlying collateral. This represented an ever growing inverted pyramid of credit on a given source of payments

\footnotetext{
${ }^{7}$ Haldane (2009).

${ }^{8}$ Scott and Taylor (2009).
} 
and greatly increased the overall degree of leverage in financial markets and the fragility of the system to shocks that affected the value of the collateral.

Lastly, the engineers apparently failed to recognize that information, particularly soft information, does not travel well down a chain of connected securities from the originator to the ultimate investors. Parts are lost or modified in the process. Thus, the quality of information is likely to vary more both across securities with the same underlying characteristics and among individual investors for complex securities more so than for simpler securities. Asymmetric information problems become more severe. The complexity and uncertainty makes these securities difficult to price accurately. Dealer spreads become exceptionally wide, discouraging trade and reducing liquidity in these markets.

Government

The federal government, both Congress and the administration, actively promoted home ownership, in particular for low income and minority households. In the process, it encouraged and, at times, required mortgage lenders, particularly the two large quasigovernment housing finance agencies - Fannie Mae and Freddie Mac - to provide loans in amounts equal to a substantial percentage of their mortgage lending to high risk low income and minority (subprime) borrowers at market rates of interest ex-ante often below those for that borrower risk class and ex-post below those commensurate with the large losses actually realized. The large investment in these securities led to the ultimate insolvency of both Fannie and Freddie, at a very high cost to the taxpayer.

To encourage their purchases of such mortgages, these two agencies had been permitted by the government to operate at capital ratios considerably lower than those for 
commercial banks and thrift institutions and with weaker regulatory supervision. Nor did the government declare in sufficiently strong and credible terms that the governmentsponsored enterprise debt securities did not have the full faith and credit backing of the U.S. Treasury. Investors did not appear to accept the weaker statements made at face value. Thus, the securities traded at yields above Treasuries but below those on noncorporate bonds. When the GSEs failed, the government protected all the debt holders at full value, allowing them to keep the premium yields collected. The federal government effectively subsidized the excessive risk-taking.

The government also encouraged and at times even required the extension by some lenders of low - near zero - down-payment mortgage loans, often with the backing of government agencies such as Fannie, Freddie and the Federal Housing Administration. These highly leveraged mortgages performed poorly and defaulted at high rates when the value of the home declined below the value of the loan or the borrower experienced financial difficulties and could not or would not make their monthly payments. Default rates and the financial turmoil tended to be less in countries that did not permit such highly leveraged and risky home mortgages, e.g., Canada. ${ }^{9}$

\section{Investors}

Investors (buy side) are the ultimate lenders. ${ }^{10}$ Many investors failed to do proper credit evaluations and due diligence on the complex mortgage securities that they purchased. To do so required more financial knowledge and training than many individual and even some institutional investors possessed. As noted earlier, mortgage

\footnotetext{
${ }^{9}$ A number of other features unique to residential mortgages in the U.S. contribute to their being riskier, such as being nonrecourse in most states.

${ }^{10}$ Almost all of the investors in complex mortgage and other debt instruments are institutional investors banks, pension funds, insurance companies, hedge funds, etc. There are few retail investors, although some are involved indirectly through participation in their pension funds.
} 
CDOs often were based on a large number of individual mortgages with documentation running tens of thousands of pages and at times also incorporated nonmortgage loans. Proper credit analysis required more time than many investors were accustomed, or willing and able, to devote to this task. As a result, they outsourced much of the credit analysis to the credit rating agencies, which, again as noted earlier, failed to be as careful and accurate in their analyses as generally perceived. In addition, as many of these complex securities were new, opaque, and little understood, they incurred innovation risk that accompanies almost any new product, be it automobiles, airplanes, steam engines, or original issue junk corporate bonds. The first three innovations saw large numbers of serious injuries and deaths among the pioneers before safety was improved. The last were the subprime mortgage bonds of the 1980s and suffered almost equally poor performance immediately after their introduction. But now, some 30 years later, junk bonds are an accepted part of the corporate bond market and represent some 20 percent of the overall size of the market.

Many investors were caught up in the euphoria of the housing bubble and healthy state of the economy and failed to charge more realistic credit risk premiums on the securities that they purchased. These premiums were at record low levels above Treasury securities. In this low premium environment, some investors assumed that credit ratings held across security classes and reached for securities that offered higher spreads than similarly rated securities in other classes. Many of these were the newly introduced, more complex derivative securities. The higher market spreads reflected higher market estimates of risk, but in retrospect were not high enough. When the crisis hit, such investors suffered large losses. 
Lastly, as noted earlier, some investors are limited by law or regulation to types of securities they may purchase, such as "safe" bonds as gauged by being rated in the top one or two credit ratings. The increased investor demand for such bonds helped to create an increase in supply through the protection of highly rated tranches of CDO or CDO-like securities. In addition, to further increase the number of such eligible bonds, particularly those with higher yields, some of these investors exerted pressure on the rating agencies to upgrade securities on the margin to the permissible ratings.

\section{Mortgage Borrowers}

During the bubble period, an increasing number of mortgage borrowers borrowed on the basis of anticipated increases in residential house prices rather than on their current income and on mortgages that permitted amortization and/or interest payments to be deferred (Alt-A mortgages). When the bubble burst and home prices declined, these mortgages frequently went into default. Borrowers could not meet or did not want to make the monthly payments, particularly as the value of their house declined below the amount of the loan. Some borrowers also misrepresented their income, other debt, and employment situation, particularly in no documentation (doc) or minimum doc mortgages, frequently referred to as “liars’ loans.” They did so out of confidence that home prices would continue to increase, allowing them to refinance at lower interest rates as their equity increased, but in full knowledge that they could not meet the current required monthly payments only out of the their current or future income for very long. At times, this represented fraud on part of the borrower. Speculation in mortgage financing increased. 
Many borrowers refinanced their existing older mortgage loans at more recent lower interest rates. But, at the same time, they borrowed larger amounts by cashing out the increases in the equity value of their homes from the time that the existing mortgage was originated. As a result, their monthly dollar payments increased. This practice also increased the leverage and the riskiness of their mortgages.

Mortgages, even plain vanilla fixed-rate long-term mortgages, are complex financial instruments, for example, incorporating call options in the form of prepayment provisions, that are difficult to understand by the average mortgage borrower. And the complexity increases with additional features, such as variable rate mortgages, step-up mortgages, interest only mortgages, and option payment mortgages. Fewer borrowers understand these contracts. Many were deceived to their later sorrow by favorable promised outcomes. They failed to take heed that "if something is too good to be true, it likely isn’t true.”

\section{Mortgage Brokers}

Mortgage brokers are salesmen and may be expected to act as they do in any other industry, e.g., used automobiles. But since mortgages are more complex and opaque than most other consumer products, asymmetrical information is a greater problem in the mortgage market generally to the disadvantage of the borrower. Brokers tend to be compensated on the basis of the number and dollar value of mortgages they originate and, as they do not hold the mortgage as investments beyond warehousing, they are compensated with little or no consideration of those mortgages's later performance. Thus, the broker's incentive is primarily to sell, regardless of the quality of the product. 
Traditional mortgage origination underwriting standards effectively collapsed. As noted, in recent years brokers often originated mortgage loans aggressively on excessive reliance on overly optimistic expectations of increases in house prices and on insufficient and undocumented, unverified, and even fabricated information on the borrower's income, employment, and other debt outstanding. Mortgages were also extended on the basis of broker initiated and driven deliberately falsified overstatement of borrower income and ability to make the required monthly payments, particularly after the end of low, temporary teaser rates on variable rate mortgages, understatement of monthly payments by omitting escrow accounts, and other misrepresentations. The last practices often represented broker fraud and appear to have been perpetrated disproportionately on those least likely to understand the nuances of the mortgage contract, e.g., low income and minority households. The liberalization of underwriting standards increased the demand for home ownership and contributed to the bubble in home prices.

\section{Prudential Bank Regulators}

In retrospect, there were numerous signals and red flags in the early 2000s warning of a potential financial meltdown to come. But, just as the U.S. intelligence services have recently been accused of doing in the war on terrorism, financial regulators may also be accused of failing to "connect the dots."

Most importantly, the regulators failed to require banks to maintain sufficient correctly measured capital to absorb unexpected losses, particularly in a bubble environment. The Federal Reserve and Comptroller of the Currency both strongly supported permitting the minimum regulatory capital requirement for large banks to be computed in the future by the advanced internal models approach for risk-based capital 
(capital to risk-weighted assets) developed in Basel II. For most of these banks, this would have lowered their minimum regulatory capital ratio from that currently in force, computed under Basel I.

Moreover, these regulators generally were also opposed to maintaining the simple leverage ratio of capital to total assets, which is one of the three regulatory capital ratios required of U.S. banks in the Federal Deposit Insurance Corporation Improvement Act (FDICIA) of 1991 and was the binding constraint for most large banks in the pre-crisis period. ${ }^{11}$ The other two capital ratios are risk-based. Based on a trial run impact survey of 26 large U.S. banks conducted by the regulators in 2005, the computed minimum regulatory capital requirement for credit risk would have been reduced for these banks by some 16 to 22 percent on average from Basel I. ${ }^{12}$ Only two of the 26 banks surveyed would have had enough capital to be classified as “adequately capitalized” by the inplace FDICIA simple leverage ratio criterion and fully 10 banks would have been classified as "critically undercapitalized” with equity capital-total asset ratios of less than 2 percent. Only the support of the FDIC kept the leverage ratio from being effectively discarded and banks from likely having to hold even less capital than they did. ${ }^{13}$

\footnotetext{
${ }^{11}$ For example, Susan Bies, then a member of the Board of Governors of the Federal Reserve System, was quoted as saying in a talk to bankers that:

The leverage ratio down the road has got to disappear. I would say to the industry, if you work with us and be patient, we understand the concerns about leverage ratios and as we get more confidence in the new risk-based approach, it will be easier for us to move away from the leverage ratios.
}

Governor Bies later argued that this was a poor choice of words on her part and that she was

misinterpreted. (Bies, 2005).

${ }^{12}$ Kaufman (2006).

${ }^{13}$ Sheila Bair, Chairman of the FDIC, testified before the Congress in August 2009 that: During the discussions of the Basel II Advanced Approaches, the FDIC voiced deep concern about the reductions in capital that would have resulted from its implementation.... It is highly likely that the advanced approaches of Basel II would have been implemented much more quickly and with fewer safeguards, and banks would have entered the crisis with much lower levels of capital. In particular, the longstanding desire of many large institutions for the elimination of the leverage ratio would have been much 
In retrospect, banks were vastly over-leveraged for the risk environment in which they were operating. ${ }^{14}$ The U.S. regulators’ fascination with Basel also had another cost. Some of the best minds at the regulatory agencies, as well as at banks, academe, and consulting firms, were detailed to working on developing and improving Basel I and particularly Basel II, rather than working on more important issues discussed below. ${ }^{15}$

The agencies were insufficiently concerned with financial stability in the broad or macro sense. The U.S. was the only industrial country to neither prepare or publish a financial stability report nor participate in the IMF-World Bank financial sector assessment program. ${ }^{16}$ Thus, the agencies were not as focused as they might have been either on the horizontal interaction of financial institutions with each other as opposed to the vertical silo approach of individual bank holding companies or on the interaction of the financial sector as a whole with the macroeconomy.

Nor did the agencies aggressively enforce the provisions of prompt corrective action (PCA) specified in FDICIA. These provisions required regulators to apply first discretionary and then mandatory progressively harsher sanctions on banks when their financial condition deteriorated sufficiently to trigger specified progressively lower capital ratios tripwires in order to try to turn financially troubled banks around and to legally close a bank and place it in receivership when this fails and its equity capital to total assets ratio declined below 2 percent. Indeed, the Inspector General of the Treasury Department accused the Office of Thrift Supervision (OTS) of permitting six thrift

more likely to have been realized in a regulatory structure in which a single regulator plays the predominant role (Bair 2009b).

${ }^{14}$ This conclusion was also reached in a recent report by the GAO (2009).

${ }^{15}$ Kaufman (2007).

${ }^{16}$ Oosterloo et al (2007). The only other industrial country not to publish a financial stability report was Italy. 
institutions to backdate the timing of the receipt of capital injections from their parent thrift holding companies to avoid the timely imposition of sanctions or even possible closure. ${ }^{17}$ Two of these institutions were subsequently closed with an estimated combined loss to the FDIC of near $\$ 15$ billion. The other bank regulators received only slightly higher marks. ${ }^{18}$

Nor do the large losses to the FDIC in the closing of the other failed banks suggest that the regulators legally closed these banks promptly when their book value equity declined below 2 percent of their assets as encouraged by FDICIA. FDIC losses in 2008 and 2009 frequently were in the 20 to 40 percent of asset range. Mandatory sanctions and closure were specifically included in FDICIA to reduce if not eliminate regulatory agency forbearance, which was prevalent during the S\&L crisis of the 1980s and the cause of larger than necessary losses. ${ }^{19}$

The regulators were also unprepared to resolve large, systemically important insolvent banks and other financial institutions and deal with the expected contagious spillover effects. They were never able to convince the market that no bank was "too big to fail” and that de jure uninsured depositors and other creditors would suffer pro-rata losses in these failures. The regulators resolved large insolvent institutions inconsistently, differing from institution to institution in terms of timing and loss allocation on what appeared to be ad-hoc criteria. This uncertainty contributed significantly to the depth and length of the crisis. ${ }^{20}$

\footnotetext{
${ }^{17}$ Thorson (2008), Hopkins (2009), and Office of Inspector General (2009).

${ }^{18}$ Garcia (2010). Many of these criticism apply also to the Securities and Exchange Commission, which had regulatory authority over investment banks.

${ }^{19}$ Benston and Kaufman (1994).

${ }^{20}$ It may be argued that the Fed assisted in bailing out Bear Stearns in March 2008 primarily because it was caught by surprise and not prepared to place it in Chapter 11 receivership. This likely affected the market's expectation on how Lehman Brothers would be resolved and its response when it was not. The regulators
} 
In the U.S., the legal structure for the resolution of insured banks differs importantly from that for the resolving other corporations. The resolution of insolvent large banks is complicated as the banks are owned by parent holding companies that, along with any of their nonbank subsidiaries, are subject to general corporate bankruptcy statutes (Chapters 7 and 11), while resolution of the bank is subject to the provisions of the Federal Deposit Insurance Act (FDIA).

These two insolvency resolution regimes differ substantially. ${ }^{21}$ Bank regulators are able to legally close insured banks, but not bank holding companies, as they approach or reach insolvency and place them in receivership or conservatorship rather than waiting for the marketplace and the courts to do so. The regulators rather than the courts act as the administrator of the receivership or conservatorship. They may act to continue the critical services of the closed bank on an almost seamless basis by having greater flexibility than the courts in either imposing pro-rata realized losses on uninsured depositors and other creditors and the determination of the timing of their access to their funds or, if they believe that imposing such losses would contribute to financial instability, protecting them partially or totally against loss. The regulators may also terminate the existing management of failed large banks and select new management at newly chartered successor bridge banks. Thus, the regulators have greater powers and freedom to shape the resolution of insolvent "too-big-to-fail” institutions than the courts have under the general corporate bankruptcy regime.

were also caught by surprise by the problems at the giant insurance company AIG in September 2008, to which they provided large-scale financial assistance at the same time they denied aid to Lehman.

${ }^{21}$ Bliss and Kaufman (2007). 
Resolution of large banks is also made difficult as many are likely to operate in different countries with different legal jurisdictions and different resolution regimes. ${ }^{22}$ Each country is likely to try to minimize its own losses through ring fencing as many of the bank's assets in the country as possible. Regardless of the resolution regime involved, it is important that all parties know in advance the rules by which insolvency will be declared and resolved so that they can plan their policies and strategies to best avoid this fate.

Some agencies claim that they have conducted "war game” type insolvency resolution simulations, but were reluctant to share the process with the public for fear of starting bank runs. But secret resolution plans are little or no better than no plans! Without known or specific guidelines, banks and other affected institutions cannot plan useful strategies, customers cannot judge the solvency of their institutions, and the regulators cannot predict what strategies the troubled institutions will take. The greater the uncertainty about failure resolution policies, the less efficient and predictable will be a bank’s operations and their customers' behavior. ${ }^{23}$

The regulators failed to require mandatory subordinated debt to be issued by at least large banks as proposed by many students of banking for many years. The market interest yields on such credibly uninsured securities could supplement the supervisors’ own evaluation of a bank's financial health and/or feed into the PCA tranches directly and trigger sanctions. ${ }^{24}$

\footnotetext{
${ }^{22}$ Hupkes (2003).

${ }^{23}$ Advance knowledge of the resolution regime is also necessary to maximize the usefulness of recently proposed "living will" exercises for large banks and other large complex financial firms.

${ }^{24}$ Because during the crisis the regulators guaranteed many of the large debt liabilities of banks, including subdebt, the future of subdebt as credibly uninsured has been compromised, reducing its ability to provide useful market signals.
} 
The regulators also failed to monitor adequately both the size and ownership of the complex securitized mortgage instruments that were a root cause of the crisis or to be sufficiently sensitive to the existence of off-balance sheet affiliates that many larger banks established to create and distribute these securities. As discussed earlier, to reduce both their reported risk exposure and capital requirements, many larger banks transferred some of their cash inflows from whole mortgage loans or mortgage backed securities that they originated or purchased to a separately organized and capitalized SIV that transformed the cash flows into multi-tranched securities for sale. But, to minimize the originating bank’s reputational risk, there frequently were implicit agreements that, in case of credit difficulties, the originating bank would repurchase the securities. This put the securities, often with large unrealized losses, back on the bank's own balance sheet at times of trouble.

The prudential regulators also failed to be sufficiently sensitive to the riskiness of many of the subprime mortgages that had been extended in the early 2000s. As noted earlier, many of these were highly complex, incorporated insufficient borrower information, and involved questionable and at times fraudulent underwriting practices. The regulators had the authority under the Home Ownership and Equity Protection Act (1994) to restrict features of residential mortgage contracts that they considered inappropriate, deceiving, or abusive. But, they failed to propagate such restrictions until after the crisis had begun. ${ }^{25}$ It should be noted, however, that even if the regulators had promulgated more restrictive rules earlier, the actions may have been challenged and opposed by both Congress and the industry. Given the euphoria of the day, they might

${ }^{25}$ Bair (2009a and 2010) and Appelbaum (2009). 
have viewed any restrictions as primarily restricting the opportunity of low and minority households to participate in the benefits of home ownership.

The argument above suggests that a major problem with the prudential regulators is an agency problem. The regulators appear to have been rather poor agents for their healthy bank and taxpayer principals. Before the crisis, they failed to enforce either the letter or the spirit of the rules that were on the books. ${ }^{26}$ This contributed to the setting for the crisis. The regulators had their own agenda, which appears to have been driven by a combination of a reluctance to “punish” the industry that they are regulating through what may be conceived to be unduly harsh measures (industry capture), reluctance to abandon a discretionary "I know better than the prescribed rules" attitude, and fear that official recognition of serious and costly bank failures and financial meltdowns on their watch that would both ignite fear in the public and damage their own reputations as protectors of bank safety. All these characteristics lead to regulatory forbearance. ${ }^{27}$ Among the many sinners, the prudential regulators appear to bear a disproportionate responsibility for the severity of the problem. If so, this suggests caution in propagating new rules and regulations until the agency problem is solved. They may not be enforced when the regulators prefer not to. ${ }^{28}$

\section{Conclusion}

This paper identifies many of the more important sinners who contributed to both igniting and fueling the financial meltdown of 2007-09 and discusses briefly the nature of

\footnotetext{
${ }^{26}$ Many of the new powers requested by the Obama Administration and Treasury Secretary Geithner from Congress appear to have been permitted by the appropriate agencies before or during the crisis without required additional congressional approval (Geithner 2009).

${ }^{27}$ Unlike the Federal Reserve and the FDIC, both the Office of the Comptroller of the Currency and Office of Thrift Supervision are financed by fees imposed on their member institutions. Loss of membership may result in shrinkage of the agency. Fear of this may cause these agencies to be less tough on their institutions that other wise and effectively be equivalent to industry capture.

${ }^{28}$ The relative benefits of regulator and market discipline are reviewed in Hetzel (2009).
} 
their more important sins. All sinners do not bear equal responsibility, but without each, the crisis would have been less serious. By permitting risky home mortgages and then encouraging their widespread use and by not enforcing regulations that were in place, the government and prudential regulators, respectively, appear to be at least as important sinners as the private sector.

Because effective corrective actions require correct identification of the causes of the crisis, we study the past in order to attempt to prevent repeating the same errors in the future. The Spanish-American philosopher George Santayana (1863-1952) admonished us that "those who cannot remember the past are condemned to repeat it." Thus, if they do remember the past, they may avoid repeating their errors. Santayana was an optimist. He assumed people learned from their past errors. However, my experience is that most if not all policy makers do remember at least some of the past. What then have they done? I am a cynic. People do not always learn from their errors. My observation is that "those who can remember the past are condemned to agonize first and then to repeat it.” And unfortunately, my reading of the behavior of almost all involved parties in the period leading up to and during the recent financial crisis appears to support this conclusion. I only wish I could conclude otherwise! Nevertheless, attempts to identify the true causes of the crisis in order to design and adopt appropriate corrective policies cannot hurt. 


\section{References}

Acharya, Viral V. and Matthew Richardson (2009). "The Financial Crisis of 2007-2009: Causes and Remedies.” Financial Markets, Institutions and Instruments 18 (2): 89-137. http://www3.interscience.wiley.com/cgi-bin/fulltext/122241546/PDFSTART.

Appelbaum, Bin Yamin (2009). "Fed Broadens Its Overnight to Include Subprime Lenders.” Washington Post, September 16. http://www.washingtonpost.com/wpdyn/content/article/2009/09/15/AR2009091503311.html.

Bair, Sheila C. (2009a). "Statement Before the Committee on Banking, Housing and Urban Affairs.” Washington, DC: U.S. Senate. March 19.

http://banking.senate.gov/public/index.cfm?FuseAction=Files.View\&FileStore_id=3fba 1cc8-b8d7-41fd-b0b4-7ea5da420587.

Bair, Sheila C. (2009b). "Statement Before the Committee on Banking, Housing and Urban Affairs.” Washington, DC: U.S. Senate. August 4.

http://banking.senate.gov/public/index.cfm?FuseAction=Files.View\&FileStore_id=e51a f9e9-768a-48d2-b148-eaa73435a12e.

Bair, Sheila C. (2010). "Statement on the Causes and Current State of the Financial Crisis Before the Financial Crisis Inquiry Commission.” Washington, DC: Federal Deposit Insurance Corporation. January 14. http://www.fdic.gov/news/news/speeches/chairman/spjan1410.html.

Bank for International Settlements (2009). Annual Report. Basel, Switzerland. June 29. http://www.bis.org/publ/arpdf/ar2009e.htm.

Benston, George J. and George G. Kaufman (1994). “The Intellectual History of the Federal Deposit Insurance Corporation Improvement Act of 1991,” in George Kaufman, ed., Reforming Financial Institutions and Markets in the United States. Boston: Kluwer Academic.

Bernanke, Ben S. (2010). “Monetary Policy and the Housing Bubble.” Washington, DC: Board of Governors of the Federal Reserve System. January 3.

http://www.federalreserve.gov/newsevents/speech/bernanke20100103a.pdf.

Bies, Susan (2005). "Statement of Susan Schmidt Bies, Member, Board of Governors of the Federal Reserve System before the Committee on Banking, Housing, and Urban Affairs, United States Senate.” Washington, DC: U.S. Senate Committee on Banking, Housing and Urban Affairs. November 10.

http://banking.senate.gov/public/index.cfm?FuseAction=Hearings.Hearing\&Hearing_ID =3d3a34d6-0be5-4bcc-b381-1a0ab5d8e0ac

Bliss, Robert R. and George G. Kaufman (2007). “U.S. Corporate and Bank Insolvency Regimes: A Comparison and Evaluation.” Virginia Law and Business Review (Spring): 143-177. 
Eisenbeis, Robert A. and George G. Kaufman (2009). “ Lessons from the Demise of the U.K.'s Northern Rock and the U.S.'s Countrywide and IndyMac,” in F. Bruni and D.T. Llewellyn, The Failure of Northern Rock (Vienna: SUERF). 73-113.

Garcia, Gilliam G.H. (2010). "Failing Prompt Corrective Action,” Working Paper, January 20.

Geithner, Timothy F. (2009). "Statement Before the House Financial Services and Agricultural Committees” Washington, DC: U.S. House of Representatives. July 10. http://www.house.gov/apps/list/hearing/financialsvcs_dem/otc_derivatives_07-0909_final.pdf.

Haldane, Andrew G. (2009). “Rethinking the Financial Network.” Amsterdam: Financial Students Association. April 28. http://www.bankofengland.co.uk/publications/speeches/2009/speech386.pdf.

Hetzel, Robert L. (2009). “Should Increased Regulation of Bank Risk-taking Come From Regulators or from the Market?” Federal Reserve Bank of Richmond Economic Quarterly 95 (2): 161-200.

http://www.richmondfed.org/publications/research/economic_quarterly/2009/spring/pdf/ hetzel1.pdf.

Hoenig, Thomas M. (2009). “Maintaining Stability in a Changing Financial System.” Kansas City: Federal Reserve Bank of Kansas City Economic Review (Quarter I): 5-16.

Hopkins, Cheyenne (2009). “Treasury IG Faults OTS for Allowing Backdating.” American Banker (May 22).

Hupkes, Eva H.G. (2003). “Insolvency: Why a Special Regime For Banks?,” in Current Developments in Monetary and Financial Law (Vol. 3). Washington, DC: International Monetary Fund.

Kaufman, George (2007). "Basel Has Been a Costly Distraction on the Road To Minimizing the Societal Cost of Bank Failures.” Chicago: Working Paper, Loyola University Chicago, July 10.

Mason, Joseph R. and Joshua Rosner (2007). "Where Did The Risk Go? How Misapplied Bond Ratings Cause Mortgage Backed Securities and Collateral Debt Obligation Market Disruptions” May 3. http://ssrn.com//abstract=1027475.

Office of Inspector General (2009). Safety and Soundness: OTS Involvement with Backdated Capital Contributions by Thrifts. Washington, DC: U.S. Treasury Department. May 21. 
Oosterloo, Sander, Jacob De Haan, and Richard Jong-A-Pin (2007). "Financial Stability Reviews: A First Empirical Analysis.” Journal of Financial Stability 2 (4): 337-355.

Scott, Kenneth E. and John B. Taylor (2009). "Why Toxic Assets Are So Hard To Clean Up.” Wall Street Journal, July 20: A13 .

Taylor, John B. (2009). Getting Off Track: How Government Actions and Interventions Caused, Prolonged, and Worsened the Financial Crisis. Stanford, CA: Hoover Institution Press, 2009.

Thorson, Eric M. (2008). "Letter to Senator Grassley.” Washington, DC: U.S. Treasury Department, December 22. http://grassley.senate.gov/news/upload/IndyMac-12-22-08Eric-Thorson-s-letter-to-CEG.pdf.

U.S. Government Accountability Office (2009). Financial Market Regulation: Financial Crisis Highlights Need to Improve Oversight of Leverage at Financial Institutions and Across System. Washington, DC: U.S. Government Accountability Office. GAO-09-739. July 22. http://www.gao.gov/new.items/d09739.pdf.

Wallison, Peter J. (2009). "Deregulation and the Financial Crisis.” Financial Services Outlook (October 31). Washington, D.C : American Enterprise Institute. http://www.aei.org/docLib/10-FSO-October-g.pdf. 